\title{
Risk Management for Truck-LHD Machine Operations in Underground Mines Using Failure Modes and Effects Analysis
}

\section{Muharrem Kemal Özfırat ${ }^{1^{*}}$, Mustafa E Yetkin ${ }^{1}$ and Pınar Mızrak Özfırat ${ }^{2}$}

\author{
${ }^{1}$ Engineering Faculty, Department of Mining Engineering, Dokuz Eylul University, Buca-Izmir, Turkey \\ ${ }^{2}$ Engineering Faculty, Department of Industrial Engineering, Celal Bayar University, Yunusemre-Manisa, Turkey
}

\begin{abstract}
In underground metal mines, cross-sections of galleries can be made larger compared to coal mines. Therefore, underground mining trucks Load-Haul-Dump (LHD) machines can easily be used for haulage of ore in underground metal mines. Ore produced is taken by LHD machines and moved to transfer points where trucks are waiting. Ore is loaded to trucks at transfer points and moved out of the mine. In this study, risks in transfer operations of ore from LHD machines to trucks are considered using Failure Modes and Effects Analysis. Risks which turn out to have risk priority number greater than 100 are handled urgently and risks priorities are decreased with the necessary precautions.
\end{abstract}

\section{Keywords}

Underground metal mine, LHD, Underground truck, FMEA

\section{Introduction}

Failure Modes and Effects Analysis (FMEA) was first developed and used in aviation industry in 1960s [1]. FMEA is a method which evaluates potential hazards and, in this method, potential hazards are identified and evaluated and corrective actions are suggested to prevent the occurrence of a hazard [2]. FMEA can be applied both in manufacturing and service industries. Failure mode is defined to be the potential failure state in the system, product, process etc. [3]. Today, FMEA is commonly used in many areas such as aviation, automotive, electronics, chemistry, engineering and medical technologies [4-12].
There also exists studies which analyzes risks using FMEA in mining industry. Ozfirat [13] proposed a fuzzy FMEA methodology and employed it for an underground coal mine. Eyuboglu and Ozfirat [14] identified the potential hazards in underground metal mining and computed risk priority numbers (RPN) by FMEA. Ventilation in the mine is found to be one of the highest risks in underground metal mines. Malli, et al. [15] employed FMEA for truck accidents in open pit mining. They identified potential risk and for high priority risks, they proposed necessary engineering precautions mostly based on early warning sensors and virtual reality solutions. Ozfirat, et al. [16] also used FMEA for risk evaluation of haulage operations in underground

\footnotetext{
*Corresponding author: Muharrem Kemal Özfirat, Engineering Faculty, Department of Mining Engineering, Dokuz Eylul University, Buca-Izmir, Turkey, Tel: +902323017539

Accepted: April 13, 2019; Published: April 15, 2019

Copyright: (c) 2019 Özfirat MK, et al. This is an open-access article distributed under the terms of the Creative Commons Attribution License, which permits unrestricted use, distribution, and reproduction in any medium, provided the original author and source are credited.

Özfirat et al. Int J Ind Operations Res 2019, 2:003
} 
mining. Shariati [17] identified risks that may occur in underground mines and analyzed them using FMEA. Meraj and Farhad [18] predicted subsidence risk in underground mines using FMEA. Oraee, et al. [19] evaluated underground mining hazards by fuzzy FMEA. Amini and Mojtaba [20] studied risks that may occur during tunnel construction using FMEA.

In this study, risk analysis is carried out for transfer point operations in underground metal mines using FMEA. In underground metal mines, produced ore is first loaded to LHD machines. LHD machines transport the ore to transfer points where it is loaded to trucks. Then ore is transported of the mine by trucks. During transfer operations both LHD machines and underground trucks manoeuvrez in a narrow area. Therefore, work accidents are likely to occur during these operations. In order to identify and analyze potential hazards and risks, FMEA is employed.

\section{Hazard, Risk and Event}

World Health Organization (WHO) defines hazard as an object, certain circumstances or factors to contain negative effect for human health and the environment. In Turkish Work Safety and Health Regulations, it is defined as "existing or outcoming potential of injury, loss or damage to the employee or work environment.

Risk on the other hand is defined by International Labor Organization (ILO) as probability of occurrence of an undesirable event at a certain time or under certain conditions. In addition, WHO defines risk to be unfavorable result of an event or the factor which brings out this probability. Risk may be probability, potential difficulty or threat or a factor bringing out an undesired result [21]. In Turkish Work Safety and Health Regulations, risk is defined to be "probability of loss, injury or other harmful results due to a hazard" [22].

Another important concept in work safety literature is the work accident. Work accident is said to be "an unexpected/unplanned event which causes damage or injury" by ILO. Similarly, WHO defines work accident as "unplanned event which may result in personal injuries, damage on machinery and equipment, stoppage of production".

\section{Risk Evaluation}

Risk evaluation is the process in which the internal and external hazard sources are identified, factors that can turn these hazards into risks are defined, priorities of risks are analyzed and countermeasures are determined to decrease risks [23]. In OHSAS 18001 Work Health and Safety Management System, risk evaluation is defined as extensive process which includes estimating risk magnitude and determining whether risk is tolerable or not [21]. The objective of risk evaluation is to identify possible risks, figure out hazard sources, determine the level of risks and to settle preventive actions. Employer should perform risk evaluation and list sources of hazards, identify risks, take precautions for employers' safety. By this way, work accidents can be reduced, loss and damages can be decreased, quality and productivity can be increased. In addition, proactive approach would make the employer ready for emergency situations [24].

Main notion in risk evaluation is to take precautions which remove hazard source of the risk. If this is not possible then objective is to take precautions decreasing the probability of occurrence of such risk [25]. When starting a risk evaluation study, necessary data should be collected about the work environment. Some of the sources of data should be laws and regulations, limit values, previous measures and observations, work accident statistics, occupational disease statistics, employee involvement, inspection reports and work health and safe-

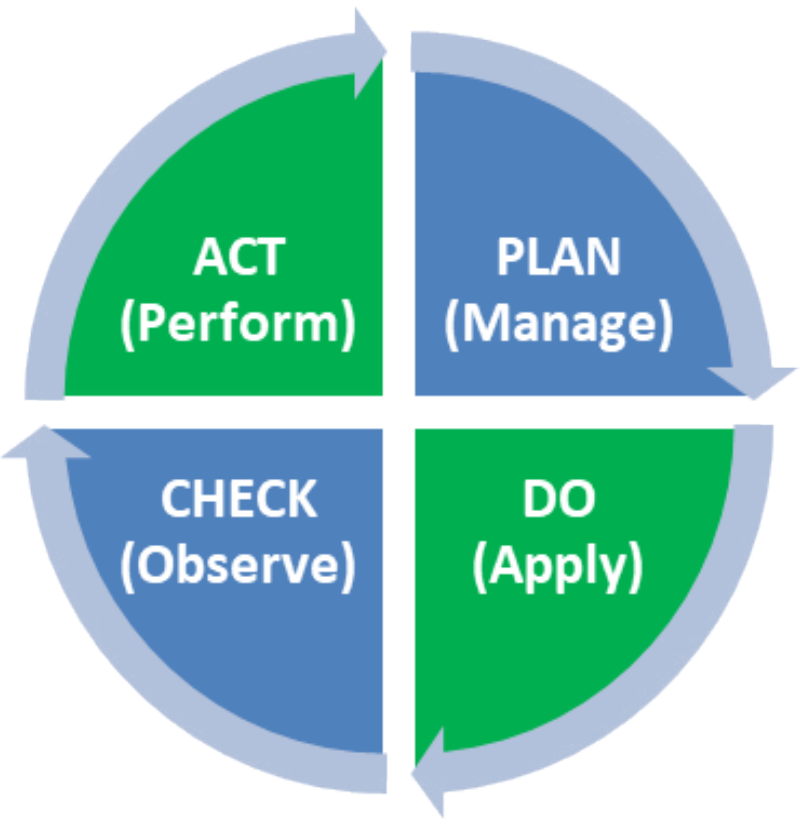

Figure 1: PDCA Cycle [21]. 
ty council reports.

Strong and weak sides of a work environment can be analyzed using the data collected from the environment. When performing this analysis, it is important to include all employees to the study and take their opinions [26]. The main objective of OHSAS 18001 Work Health and Safety Management System is to be preventive. In addition to pre- ventive actions, it also includes control systems, corrective actions and feedback mechanisms. Work health and safety is getting more important in all areas including even the environmental components. Recently, stair ascent and descent safety is studied by [27].

Work health and safety concept is based on Plan-Do-Check-Act Cycle (PDCA) according to

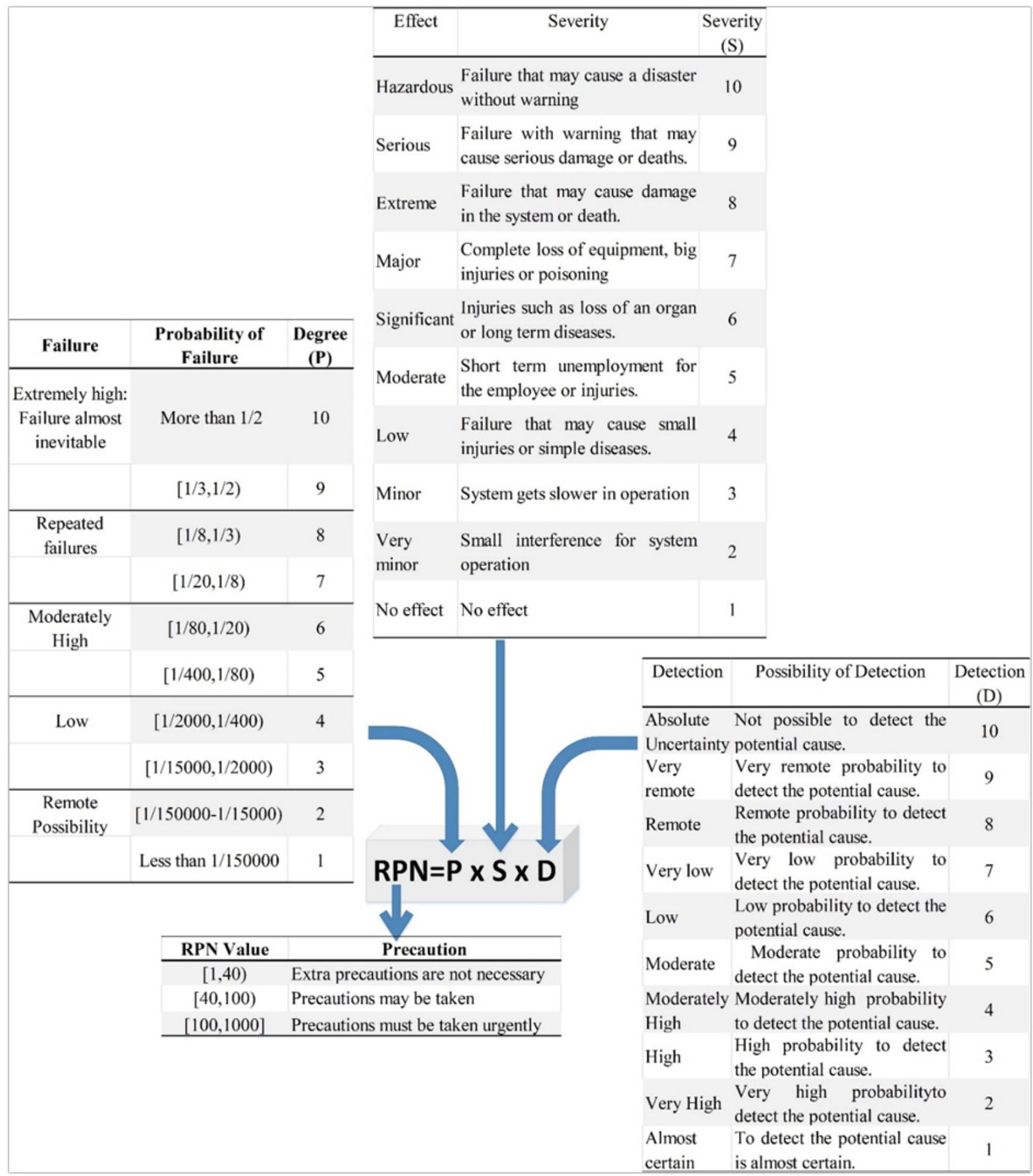

Figure 2: FMEA Tables and quantitative analysis $[3,13]$. 
OHSAS 18001 . PDCA cycle is a systematic tool to identify the reasons of variability and improve quality (Figure 1).

The Plan-Do-Check-Act Cycle can shortly be defined as follows.

- Plan: Identify a possible case where an improvement is needed. Then plan the change for the improvement.

- Do: Test the plan on a small case study.

- Check: Control the results of the study.

- Act:

o If the plan provided positive results, apply the plan to the real system. The start from the beginning for another improvement.

o If the plan did not provide desired results, change the plan, start the cycle from the beginning.

\section{Failure Modes and Effects Analysis and Case Study}

Failure Modes and Effects Analysis (FMEA) is one of the mostly used techniques in risk evaluation. Basically, FMEA concentrates on failures of systems and individual components and investigates how those failures can effect facility and processes. Then, results are analyzed which may appear due to a failure in the system or its parts [22]. FMEA was first designed for aviation industry in 1960s due to security needs. Then it is used in many different industries such as electronics, automotive etc. $[2,28]$. In 1988, FMEA standards are accepted by three important automotive corporations, Chrysler, Ford and General Motors, as general standards [28]. Today, FMEA has become compulsory in quality management systems such as QS 9000, ISO/TS 16949, ISO 9001:2000, OHSAS 18001 and TS 18001 [14].

FMEA can be considered as part of reliability engineering. It is a quantitative technique which considers the effect of three parameters in the risk. These parameters are probability, severity and detectability. Risk probability $(P)$ is the frequency of occurrence of an event. Severity (S) is the level effect of outcomes. Detectability (D) is the degree in which the risk can be figured out before it occurs. Then in the next step, by multiplying these three parameters risk priority number (RPN) is computed (Equation 1).

$\mathrm{RPN}=\mathrm{P} \times \mathrm{S} \times \mathrm{D}$

When determining $\mathrm{P}, \mathrm{S}$ and $\mathrm{D}$ levels, FMEA tables given in Figure 2 are used. After calculating RPN, risks are classified according to RPN level. If RPN is greater than 100 , precautions must be taken urgently to decrease risk level. If RPN is between 40 and 100 , precautions may be taken. If it is less than 40 , risk is tolerable (Figure 2) [3].

RPN levels directly reveal the areas with highest risks, and corrective actions should be taken for the highest priority risks. Some of the corrective actions can be listed as greater number of inspection in more detail, inspections in more number of locations, changes in design and/or processes etc. The purpose of corrective actions is to decrease probability and/or severity, to increase detectability. After corrective actions are taken, $\mathrm{P}$, $S$ and $D$ values are revised and RPN is recomputed for the risks under study. The cycle should continue until all risks are under tolerable limits [29].
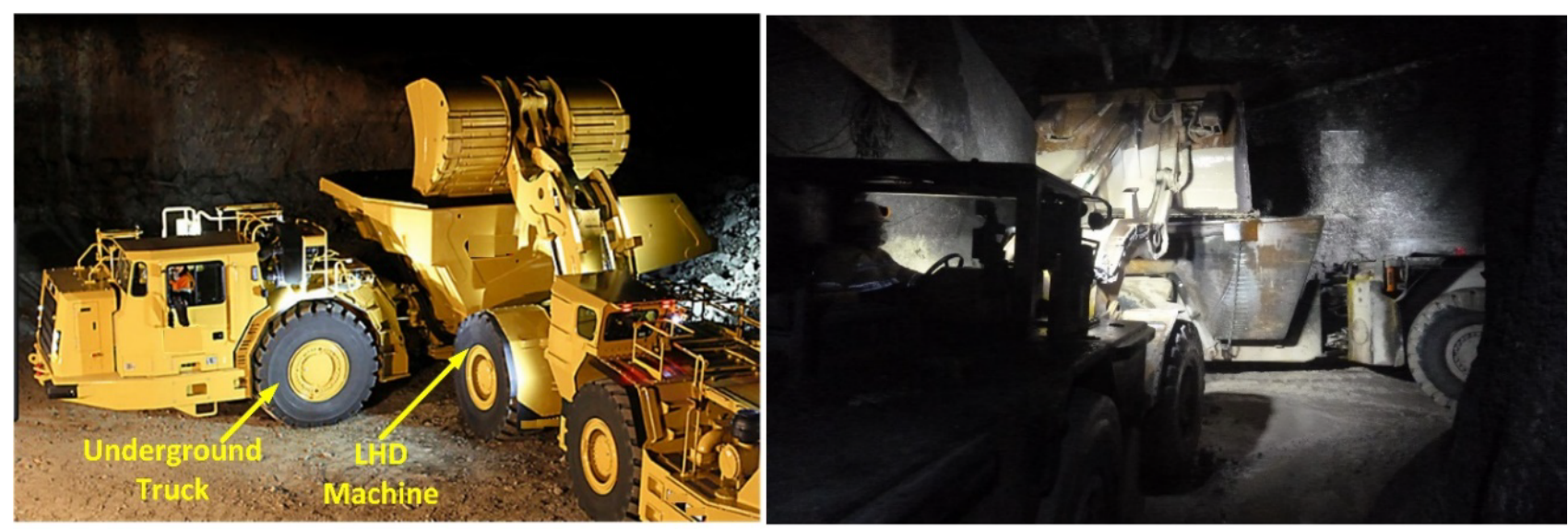

Figure 3: LHD machine and underground truck ore transfer operation in underground mines. 


\section{Case study}

In underground metal mines, ore is transferred from LHD machines to trucks at transfer points in mine (Figure 3). Since these operations are heavy duty and take place in an underground area, there may be important risks in the work environment. Therefore, in this, study, risk evaluation of truck-LHD machine ore transfer operations are considered using FMEA.

Twelve risks that may occur during truck-LHD machine ore transfer operations are identified and they are listed in Table 1 below. RPN values are computed according to probability, severity and detectability scores (Table 1).

It can be seen from Table 1 that all RPN values are greater than 100 which states that precautions must be taken urgently for all risks in the list. In Table 2, necessary precautions and corrective actions are listed for each risk. Then probability, severity and detectability scores are revised and new RPN values are computed. It can be seen that with the proposed corrective actions, RPN values are decreased in a considerable manner. Except for F9 and F11, all RPN values are decreased under 100. Since F9 and F11 risk scores cannot be decreased further, both the employer and employees should be more careful with these risks.

\section{Results and Discussion}

Twelve risks are analyzed that may take place

Table 1: Risk evaluation of the current situation using FMEA.

\begin{tabular}{|c|c|c|c|c|c|c|}
\hline \multirow{2}{*}{ Failure } & \multirow{2}{*}{ Failure type } & \multirow{2}{*}{ Risk } & \multicolumn{4}{|c|}{ Current state } \\
\hline & & & $\mathbf{P}$ & $\mathbf{S}$ & D & RPN \\
\hline F1 & $\begin{array}{l}\text { Operator does not } \\
\text { check the vehicle } \\
\text { mirrors warning } \\
\text { systems }\end{array}$ & Work machine crashes while truck or LHD is turning & 4 & 8 & 5 & 160 \\
\hline $\mathrm{F} 2$ & $\begin{array}{l}\text { Lack of control of } \\
\text { roof and support in } \\
\text { working environment }\end{array}$ & Roof falling and it threats workers and machines & 4 & 9 & 5 & 180 \\
\hline F3 & $\begin{array}{l}\text { Lack of warning noise } \\
\text { in reverse turning in } \\
\text { vehicles }\end{array}$ & Risk of crushing of workers in the loading area & 4 & 8 & 6 & 192 \\
\hline F4 & $\begin{array}{l}\text { The operator does } \\
\text { not lower the moving } \\
\text { equipment of the } \\
\text { machine to the ground } \\
\text { when machine stops }\end{array}$ & Fall down of moving equipment and accident risk & 5 & 8 & 4 & 160 \\
\hline F5 & $\begin{array}{l}\text { Failure in gallery } \\
\text { slopes }\end{array}$ & Risk of overturning of vehicles & 5 & 8 & 6 & 240 \\
\hline F6 & $\begin{array}{l}\text { Insufficient gallery } \\
\text { widths }\end{array}$ & $\begin{array}{l}\text { Crash of vehicles to the side walls of the gallery and } \\
\text { risk of injury to the operator and workers }\end{array}$ & 5 & 8 & 5 & 200 \\
\hline F7 & $\begin{array}{l}\text { Lack of warning signs } \\
\text { and reflective signs on } \\
\text { galleries }\end{array}$ & Vehicles crash to the side wall of the gallery & 6 & 6 & 5 & 180 \\
\hline F8 & Lack of lighting & $\begin{array}{l}\text { Vehicles crash to the side wall of the gallery and } \\
\text { workers }\end{array}$ & 6 & 7 & 4 & 168 \\
\hline F9 & Blind spot & Risk of crushing workers in reverse turning & 7 & 8 & 9 & 504 \\
\hline F10 & Dust & $\begin{array}{l}\text { Occupational illness risk and vision disruption due } \\
\text { to dust }\end{array}$ & 7 & 7 & 5 & 245 \\
\hline F11 & Lack of maintenance & $\begin{array}{l}\text { Risk of accident due to unexpected breakdown of } \\
\text { vehicles }\end{array}$ & 6 & 8 & 8 & 384 \\
\hline F12 & Rock particles & Risks to be caused by rock particles in production & 6 & 7 & 4 & 168 \\
\hline
\end{tabular}


during transfer operations between trucks and LHD machines in an underground mine. In the current state, blind spot risk (F9) turned out to be the highest priority risk (RPN $=504$, Table 1 ) and should be urgently resolved. In order to decrease this value to a reasonable limit, additional blind spot mirrors should be installed both on the vehicles and gallery corners. By this way, the risk value can be decreased to 100 (Table 2). At this point, probability, severity and detectability values of the risk is decreased according to Siemens approach [29]. The risk can be manageable with regular cleaning and usage of blind spot mirrors. However, still the operators and other employees as well as the employer should be careful and should track this risk closely.

Lack of maintenance (F11) is turned out to be the second highest risk with RPN value of 384 (Table 1). Periodic maintenance of the vehicles and keeping these records in written forms are the proposed corrective actions. In addition, vehicle operators should be informed of these maintenances and records. By this way, RPN value can be decreased to 100 (Table 2) and the risk turns to be manageable.

Failure in gallery slopes, insufficient gallery

Table 2: Risk evaluation after corrective actions using FMEA.

\begin{tabular}{|c|c|c|c|c|c|c|}
\hline \multirow{2}{*}{ Failure } & \multirow{2}{*}{ Failure type } & \multirow{2}{*}{ Corrective action } & \multicolumn{4}{|c|}{ After corrective action } \\
\hline & & & $\mathrm{P}$ & $S$ & D & RPN \\
\hline F1 & $\begin{array}{l}\text { Operator does not check } \\
\text { the vehicle mirrors, } \\
\text { warning systems }\end{array}$ & $\begin{array}{l}\text { Writing instructions in the vehicle and explaining } \\
\text { the subject in the trainings }\end{array}$ & 3 & 5 & 3 & 45 \\
\hline F2 & $\begin{array}{l}\text { Lack of control of roof } \\
\text { and Support in working } \\
\text { environment }\end{array}$ & $\begin{array}{l}\text { Repairing of the deteriorating places by shotcrete } \\
\text { and roof bolt by controlling the roof and support }\end{array}$ & 3 & 7 & 3 & 63 \\
\hline F3 & $\begin{array}{l}\text { Lack of warning noise } \\
\text { in reverse turning in } \\
\text { vehicles }\end{array}$ & Audible warning signal during turning back & 3 & 6 & 4 & 72 \\
\hline F4 & $\begin{array}{l}\text { The operator does } \\
\text { not lower the moving } \\
\text { equipment of the } \\
\text { machine to the ground } \\
\text { when machine stops }\end{array}$ & $\begin{array}{l}\text { Explaining loaded or empty bucket should be put } \\
\text { on the ground in trainings. Adding warning system } \\
\text { to the vehicles in case. }\end{array}$ & 3 & 6 & 3 & 54 \\
\hline F5 & Failure in gallery slopes & $\begin{array}{l}\text { Keeping the slope at a maximum of } 8^{\circ} \text { in road } \\
\text { designs }\end{array}$ & 4 & 6 & 4 & 96 \\
\hline F6 & $\begin{array}{l}\text { Not enough gallery } \\
\text { widths }\end{array}$ & $\begin{array}{l}\text { Gallery widths should be at least two vehicles wide } \\
\text { and there should exist vehicle turning pockets at } \\
\text { some points }\end{array}$ & 3 & 6 & 3 & 54 \\
\hline F7 & $\begin{array}{l}\text { Lack of warning signs } \\
\text { and reflective signs on } \\
\text { galleries }\end{array}$ & $\begin{array}{l}\text { Warning signs must be installed and cleaned } \\
\text { regularly }\end{array}$ & 4 & 4 & 3 & 48 \\
\hline F8 & Lack of lighting & Provide more light to the work environment & 4 & 5 & 3 & 60 \\
\hline F9 & Blind spot & $\begin{array}{l}\text { Adding additional blind spot mirrors on vehicle } \\
\text { mirrors. Blind spot mirrors should be installed in } \\
\text { gallery corners }\end{array}$ & 5 & 4 & 5 & 100 \\
\hline F10 & Dust & $\begin{array}{l}\text { Dust should be suppressed to the ground and } \\
\text { removed }\end{array}$ & 5 & 5 & 3 & 75 \\
\hline F11 & Lack of maintenance & $\begin{array}{l}\text { Periodic maintenance of the vehicles and keeping } \\
\text { these records in written forms. }\end{array}$ & 4 & 5 & 5 & 100 \\
\hline F12 & Rock particles & $\begin{array}{l}\text { Loading of large parts into the truck in a controlled } \\
\text { manner and recalculating the specific charge for } \\
\text { smaller fragmentation }\end{array}$ & 4 & 5 & 3 & 60 \\
\hline
\end{tabular}


widths and dust (F5, F6, F10) are also among the highest priority risks. The RPN values are found to be 240,200 and 245 respectively. The corrective action proposed for $\mathrm{F} 5$ is keeping the slope at a maximum of $8^{\circ}$ in road designs. After this action, RPN value can be decreased to 96 . For F6, RPN value can be reduced to 54 by making the gallery widths at least two vehicles wide and by placing turning pockets for vehicles at some points. In addition, suppressing dust to the ground and removing regularly, RPN value of F10 can be decreased to 75 (Table 2). All other corrective actions can be seen in Table 2. It can be seen that with the corrective actions all RPN values are less than or equal to 100 . However, it is important not to forget it is not possible to reduce risk probability to zero. This is called residual risk. Therefore, in addition to corrective actions, all risks should be analyzed continuously, and risk management should always be a continuous cycle.

\section{Conclusion}

FMEA is an effective tool to identify and resolve failures in products, system, work safety etc. since probability, severity and detectability characteristics of a risk are considered together. FMEA is employed both in academic studies and practical cases by many important corporations.

In this study, risk evaluation of ore transfer operations from LHD machines to underground trucks are considered using FMEA. Ore transfer operations in underground mines may be subject to a number of important risks since area is limited and heavy-duty vehicles are working in this limited area.

Twelve potential failures are identified for the case and RPN values are computed using FMEA. Then corrective actions and precautions are proposed for all the risks which are found to be urgent. Considering the corrective actions, RPN values are recomputed and all risk levels are reduced to be less than or equal to 100 . By this way, effective risk analysis and management process has started. Since risk management is a continuous process, it is recommended to track and manage risks continuously.

\section{References}

1. Bowles JB, Peláez CE (1995) Fuzzy logic prioritization of failures in a system failure mode, effects and criticality analysis. Reliability Engineering \& System Safety 50: 203-213.
2. Sankar NR, Prabhu BS (2001) Modified approach for prioritization of failures in a system failure mode and effects analysis. International Journal of Quality \& Reliability Management 18: 324-336.

3. Wang YM, Chin KS, Poon GKK, Yang JB (2009) Risk evaluation in failure mode and effects analysis using fuzzy weighted geometric mean. Expert Systems with Applications 36: 1195-1207.

4. Liu HC, Liu L, Liu N, Mao LX (2012) Risk evaluation in failure mode and effects analysis with extended VIKOR method under fuzzy environment. Expert Systems with Applications 39: 12926-12934.

5. Chang K-H, Chang Y-C, Tsai IT (2013) Enhancing FMEA assessment by integrating grey relational analysis and the decision making trial and evaluation laboratory approach. Eng Fail Anal 31: 211-224.

6. Kahraman C, Kaya I, Senvar O (2013) Healthcare failure mode and effects analysis under fuzziness. Hum Ecol Risk Assess Int J 19.

7. Song $W$, Ming X, Wu Z, Zhu B (2014) A rough topsis approach for failure mode and effects analysis in uncertain environments. Qual Reliab Eng Int 30: 473486.

8. Mentes A, Ozen E (2015) A hybrid risk analysis method for a yacht fuel system safety. Saf Sci 79: 94-104

9. Wang ZL, You JX, Liu HC, Wu SM (2017) Failure mode and effect analysis using soft set theory and COPRAS method. Int J Comput Intell Systems 10: 1002-1015.

10.Gong Y, Su X, Qian H, Yang N (2017) Research on fault diagnosis methods for the reactor coolant system of nuclear power plant based on D-S evidence theory. Ann Nucl Energy 112: 395-399.

11.Fattahi R, Khalilzadeh M (2018) Risk evaluation using a novel hybrid method based on FMEA, extended MULTIMOORA, and AHP methods under fuzzy environment. Saf Sci 102: 290-300.

12.Wang W, Liu X, Qin Y, Fu Y (2018) A risk evaluation and prioritization method for FMEA with prospect theory and Choquet integral. Safety Science 110: 152-163.

13. Ozfirat MP (2014) A new risk analysis methodology integrating fuzzy prioritization method and failure modes and effects analysis. Journal of the Faculty of Engineering and Architecture of Gazi University 29: 755-768.

14. Eyuboglu KA, Ozfirat MK (2015) Evaluating main hazards in underground metal mining by FMEA risk analysis management. Proceedings of Work Safety and Health Symposium, Adana, Turkey, 95-103. 
15. Malli T, Karakus D, Ozfirat MK, Gonen A, Kun M (2017) Mine truck accidents in open pit and risk assessment. International Symposium on Occupational Health and Safety in Mining, Adana, Turkey.

16. Ozfirat MK, Ozfirat PM, Kahraman B, Can Y, Oney $O$ (2013) Classification of risks in the underground mine during transportation using fault mode effect analysis (HTEA). International Symposium on Occupational Health and Safety in Mining, Adana, Turkey.

17.Shariati S (2014) Underground mine risk assessment by using FMEA in the presence of uncertainty. Decision Science Letters 3: 295-304.

18. Meraj R, Farhad SN (2015) Prediction of subsidence risk by FMEA using artificial neural network and fuzzy inference system. International Journal of Mining Science and Technology 25: 655-663.

19.Oraee K, Chamzini A, Basiri MH (2011) Evaluating underground mining hazards by fuzzy FMEA. SME Annual Meeting and Exhibit and CMA $113^{\text {th }}$ National Western Mining Conference, 255-259.

20.Amini A, Mojtaba F (2018) Risk assessment of Namaklan road tunnel using failure mode and effect analysis (FMEA). Tunnelling and climate change conference, Tehran, Iran.

21.Ozkilic O (2005) Occupational health and manage- ment systems and risk assessment methodologies. TISK Publishing, Ankara, Turkey.

22. Seber V (2012) Risk analysis in occupational health and safety. Journal of Electrical Engineering 445: 30-34.

23.Guller A, Gunduz T (2016) Risk analysis work on the work machines used in ports. Journal of Engineering Sciences and Design 2: 127-144.

24. Yilmaz F (2009) The European Union and occupational health and safety in Turkey: Measuring the activity level of occupational health and safety committees in Turkey. PhD Thesis, Istanbul University, Istanbul, Turkey.

25. Can EH, Yuvka S ve Beyhan S (2015) Investigation of risk assessment approaches in underground mining. International Symposium on Occupational Health and Safety in Mining. Adana, Turkey.

26. Tekin AM (2009) Risk assessment/rating.

27. Qian X, Chen G, Kattel B, Lee S, Yang Y (2018) Factorial analysis of vertical ground reaction force and required coefficient of friction for safety of stair ascent and descent. Int J Ind Operations Res 1: 002.

28.Celikdemir $H$ (2012) An application of failure mode and effect analysis in an automation line. Master Thesis, Gazi University, Ankara, Turkey.

29.www.siemens.com/plm 